\title{
The Cytotoxic and Anti-proliferative Activity of High Molecular Weight Pectin and Modified Citrus Pectin
}

\author{
Venicia Hawach, Marie-Anne Boujaoude, and Roula M. Abdel-Massih
}

Department of Biology, University of Balamand, Al-Koura, Lebanon

*Corresponding Author: Roula Abdel-Massih, PhD, Associate Professor, Department of Biology, University of Balamand, P.O. Box: 100 , Tripoli, Lebanon

Submission Date: May 30, 2016, Accepted Date: September 26, 2016, Publication Date:

September 30, 2016

\begin{abstract}
Background: Pectin is a heterogeneous polysaccharide mainly present in citrus fruits and has different biological activities.
\end{abstract}

Objective: High molecular weight Citrus Pectin and modified citrus pectin (MCP) were tested for their cytotoxic, anti-proliferative, and anti-oxidant activity.

Methods: The cytotoxicity of pectin was studied against HaCaT cell line (human keratinocyte cell line) using Trypan blue method and LDH-cytotoxicity assay. Anti-proliferative activity was assayed using a WST-1 proliferation kit. Antioxidant activity was determined using the DPPH scavenging assay.

Results: MCP and Pectin both reduced the viability of HaCaT cells in a dose dependent manner; however, MCP was found to be more cytotoxic than high molecular weight citrus pectin since it had a lower $\mathrm{IC}_{50}(300 \mathrm{ug} / \mathrm{ul})$. At non-cytotoxic concentrations, the viability of cells decreased with increase of concentration of MCP as determined by the WST-1. MCP exhibited a higher antioxidant effect than pectin ( $\mathrm{SC}_{50}$ at a concentration range between 2 and $4 \mathrm{mg} / \mathrm{ml}$ ).

Conclusion: This study suggests that MCP exhibits a stronger cytotoxic and anti-proliferative effect on HaCaT cell line than pectin. The most probable explanation of this observation is the different effects due to the variable molecular weight and exposed side-chains of MCP and high molecular weight citrus pectin.

Keywords: Cytotoxic, Anti-proliferative, Pectin, MCP, HaCaT cell line 


\section{BACKGROUND}

Pectin is a complex polysaccharide mainly present in the cell walls of higher plants. It is mostly abundant in citrus peel and apple pomace. Chemically, pectin is made up of a group of heterogeneous polysaccharides with high molecular weight. It has a central chain mainly composed of $(1,4)-\alpha$ - D-galacturonic acid-(1,2)- $\alpha$ - L rhamnose-(1) and side chains that are made up of many neutral sugars which are D-galactose, L-arabinose, D-glucose and D-xylose [1;2]. These structural elements consist of homogalacturonans called "smooth regions", rhamnogalacturonans (I and II) also termed "hairy regions", arabinogalactans (I and II), xylogalacturonans and arabinans [3].

Pectin has been shown to have different biological activities and is classified as an anticarcinogen due to its capability to detoxify metal/carcinogen [2]. It is not digested in the small intestine, but is fermented by colon bacteria producing short fatty acid chains that are involved in inhibiting colon inflammation and preventing carcinogenesis [4; 5]. Different studies attributed the importance of these fatty acids in lowering the $\mathrm{pH}$ of the colon and the reduction of colon cancer $[6 ; 7 ; 8]$.

Pectin's highly branched structure and the lack of human pectic enzymes impose their low solubility in human body which limits its use in medical drugs. Scientists generated an altered form of citrus pectin after the subjection of the pectin to enzyme or acid-alkali treatment [9]. Such modifications lead to the production of a mixture of oligomers rich in galacturonic acid along with Rhamnoglacturonan I fragments that were suggested to play a role in retarding metastasis by blocking lectins [9]. This modified citrus pectin is characterized by lower molecular weight and distinct biological activity [10].

Several researches proved that modified citrus pectin MCP could have better action on cancer prevention than high molecular weight pectin [11]. More than fifty studies have indicated the interaction of MCP with galectin-3 to stop cell proliferation or metastasis [2]. Galectin-3 is a target protein in anticancer research because when overexpressed, it promotes metastasis and protects cancer cells from apoptosis [12]. PectaSol-C is one form of commercial MCP generated by the submission of citrus pectin to a base treatment [13].

According to American Cancer Society, skin cancer is one of the most common cancers among human population and is increasing worldwide [14]. Researchers have established the $\mathrm{HaCaT}$ cell line from human adult skin keratinocytes cultured in reduced $\mathrm{Ca}^{2+}$ at elevated temperature. Processing from normal to immortalized stage requires the loss of cell senescence and thus HaCaT resulted from a UV-induced mutation in both alleles of the p53 tumor suppressor gene. Additionally, HaCaT cells manifest a loss of chromosomes 3p, 4p, and 9p enclosing senescence genes [15]. The immortalized HaCaT cells represent an early stage in skin carcinogenesis. A transfection with the oncogene Ras can lead to the conversion of the HaCaT to the benign (A5); additional genetic aberrations give the malignant (II4) tumorigenic clone conversion [16].

In this study, the cytotoxicity and anti-proliferative activity of citrus pectin and modified citrus pectin (Pectasol-C) were investigated using HaCaT cell line (Human Adult skin keratinocytes). The antioxidant activity of pectin was also investigated. 


\section{MATERIALS AND METHODS}

\section{Preparation of pectin solution}

Lyophilized high molecular weight Citrus Pectin was kindly provided by Megazyme. It was weighed and dissolved in DMEM medium at a concentration of $1 \mathrm{mg} / \mathrm{ml}$. PectaSol-C was kindly provided by EcoNugenics (Santa Rosa CA, USA) and used as the Modified Citrus Pectin (MCP). It has a low molecular weight range of less than $15 \mathrm{kDa}$ and a low degree of esterification. It was prepared by dissolving $1 \mathrm{mg} / \mathrm{ml}$ PectaSol-C in water. The solutions were filtered through $0.45 \mu \mathrm{m}$ sterile filter membranes and stored at $4^{\circ} \mathrm{C}$ for further use.

\section{Cell Lines and Culture}

The immortalized non-tumorigenic Human Keratinocyte (HaCaT) cell lines and other cell lines (benign (A5) and malignant (II4) cell lines) were kindly provided by Dr. Marwan Sabban (American University of Beirut). Cells were grown in culture medium of $2 \mathrm{mM}$ Calcium concentrations in Dulbecco's modified Eagle's medium (DMEM) to which 10\% heat-inactivated fetal bovine serum (FBS), $1 \%$ of $100 \mu \mathrm{g} / \mathrm{ml}$ penicillin-streptomycin, and $1 \%$ of $2 \mathrm{mM} \mathrm{L-}$ Glutamine were added. The cells were maintained at in a $5 \% \mathrm{CO}_{2}$ humidified incubator at $37^{\circ} \mathrm{C}$. Passaging of the cells was performed upon attaining $80 \%$ confluency via Trypsin-EDTA acknowledged treatment. Cells were next suspended in fresh medium into new cell culture flasks in a ratio of 1:3 for future experimental use.

\section{Cell Viability and Cytotoxicity assay}

Cells were seeded in a 24 -well plate (at a density of $10 \times 10^{3}$ cells/well) for 24 hours. Then the old media was replaced with the same volume of fresh media containing different concentrations $(1 \mu \mathrm{g} / \mathrm{ml}, 100 \mu \mathrm{g} / \mathrm{ml}, 300 \mu \mathrm{g} / \mathrm{ml}, 500 \mu \mathrm{g} / \mathrm{ml}$ and $750 \mu \mathrm{g} / \mathrm{ml})$ of pectin or MCP. All the tests were performed in triplicates along with a negative control consisting of media alone and a positive control consisting of $1 \mathrm{ml}$ Triton X-100 (2\%). After a further incubation for 24 hours, cell viability was then studied using the Trypan Blue Exclusion test.

Cytotoxicity was assayed by means of CytoTox 96 non-radioactive cytotoxicity assay kit (Roche Applied Sciences). Cells were seeded into 96-well microtiter plates (Thermo Labsystems) and incubated for 24 hours to allow attachment. Then they were treated with different concentrations of pectin and MCP. Cytotoxicity of pectin and its modified form on HaCaT cell line was monitored after 24 hours incubation. Released LDH from damaged cells converted the tetrazolium salt (INT) into a red formazan product. The amount of color formed is in direct correlation with the number of lysed cells. Finally, the product was measured colorimetrically at 490nm and 620nm using an ELISA microplate reader (Multiskan Ascent, Thermo Labsystems). The percentage viability corresponds to (100 - \% of cytotoxicity). All the tests were performed in triplicates along with a negative control consisting of media alone and a positive control consisting of $1 \mathrm{ml}$ Triton X-100 (2\%). Similarly, cytotoxicity of pectin and MCP on other cell lines (A5 and II-4) was also tested. 


\section{Cell Proliferation Assay}

Cell proliferation measurement was performed using the WST-1 reagent kit (Roche Applied Sciences, Mannheim, Germany). Cells were plated at an optimum density of $2.5 \times 10^{3}$ cells/well and incubated for 24 hours. Cell were next treated with different concentrations of pectin and MCP and incubated overnight. The next day, cells were incubated with $10 \mu \mathrm{l}$ of the WST1 Reagent (added for each well) for 4 hours. This method is based on the ability of the mitochondria of metabolically active cells to convert tetrazolium salt into a dark red formazan product which is measured colorimetrically using an ELISA microplate reader at $450 \mathrm{~nm}$ and a reference wavelength at $620 \mathrm{~nm}$. As a positive control, cells were treated with $50 \%$ ethanol in order to inhibit proliferation $[17 ; 18]$. The results were expressed as $\%$ inhibition of proliferation using the following formula:

Inhibition in $\%=100$ - (absorbance of treated cells/absorbance of control $\times 100)$

\section{Cell Scavenging Activity against DPPH}

This assay consists of measuring the ability of MCP and Pectin to inhibit DPPH (2, 2-diphenyl2-picryl hydrazyl) radical. DPPH is dissolved in pure ethanol and preserved in the dark at low temperature until use. Propyl gallate standard (500M) and $20 \mathrm{ul}$ of pectin or MCP were allowed to react in a $96-$-well plate with $\mathrm{DPPH}(0.1 \mathrm{mM})$ for $30 \mathrm{~min}$ at $37^{\circ} \mathrm{C}$. The absorbance was determined at $515 \mathrm{~nm}$ on an ELISA microplate reader (Multiskan Ascent, Thermo Labsystems). The control consisted of water or ethanol solvent. All tests were performed in triplicate. The scavenging activity was determined by the difference in absorbance before and after the addition of radical solution [19]:

Scavenging activity $\%=(1-$ Absorbance of sample/Absorbance of control $) \times 100$

\section{Statistical Analysis}

Data were analyzed by one-way analysis of variance ANOVA (Dunnett's test). The differences between the means of treated and control groups are considered as follows: $* \mathrm{p}<0.05$ (significant), $* * \mathrm{p}<0.01$ and $* * * \mathrm{p}<0.001$ (highly significant). All the experiments were repeated three independent times in triplicate form.

\section{RESULTS}

\section{Effect of pectin and MCP on Viability of HaCaT}

Viability of HaCaT cells was studied after a 24 hour treatment with different concentrations of pectin or MCP using the Trypan blue assay. As suggested by Ryu et al., cells were seeded at a concentration of $10 \times 10^{3}$ cells/well [20]. Cell viability decreased with increasing pectin concentration from around $82 \%$ at $1 \mu \mathrm{g} / \mathrm{ml}$ Pectin to $62.54 \%$ at $750 \mu \mathrm{g} / \mathrm{ml}$ (Figure 1). Higher pectin concentrations could not be tested due to experimental conditions. MCP had a stronger effect on decreasing viability from $81.52 \%$ at $100 \mu \mathrm{g} / \mathrm{ml}$ of $\mathrm{MCP}$ to $51.48 \%$ at $500 \mu \mathrm{g} / \mathrm{ml} \mathrm{MCP}$ (Figure 2). MCP could not be evaluated at $750 \mu \mathrm{g} / \mathrm{ml}$ due to problems in solubility. Cytotoxicity was further studied using LDH cytotoxicity assays. 


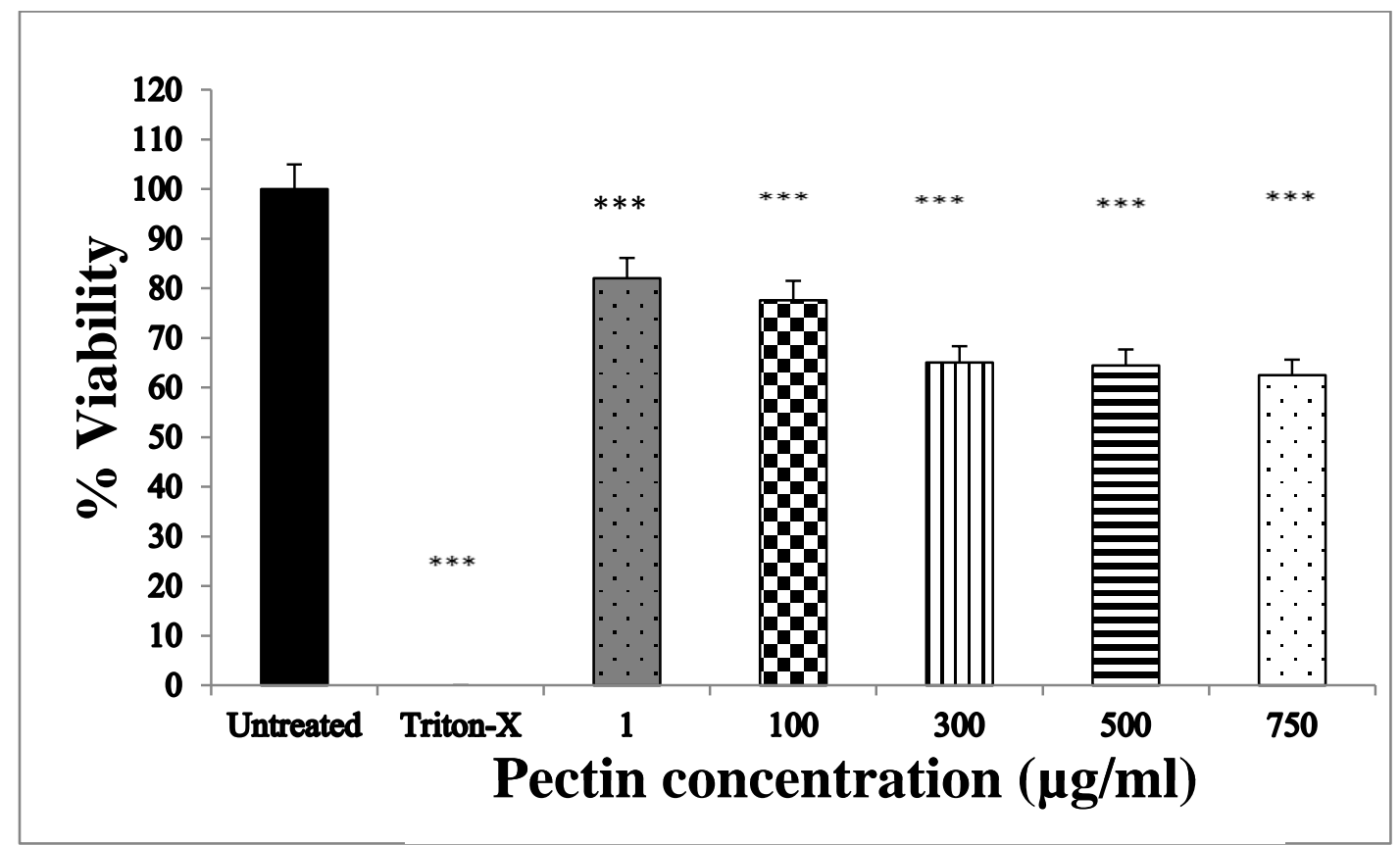

Figure 1: Effect of Pectin on the Viability of HaCaT Cell Line as Measured by Trypan Blue at 24 hours. Statistical significance of each group compared to the untreated control is determined as follows: $* \mathrm{p}<0.05, * * \mathrm{p}<0.01$ and $* * * \mathrm{p}<0.001$. The values are expressed as means of 3 independent experiments where the number of replications is 3 . Error bars represent the standard error (SE) of the results.

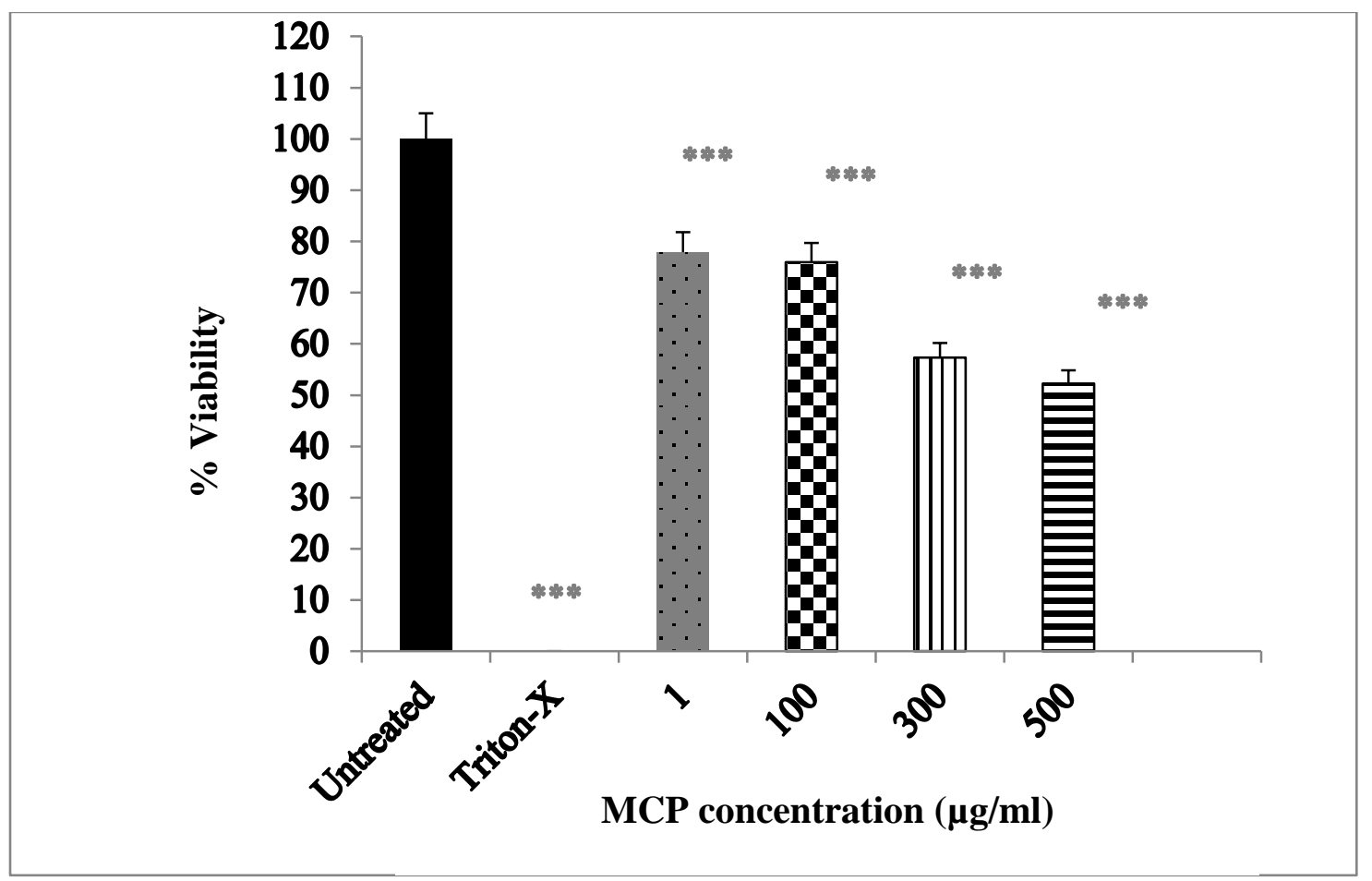

Figure 2: Effect of MCP on the Viability of HaCaT Cell Line as Measured by Trypan Blue at 24 hours. Statistical significance of each group compared to the control is determined as follows: $* \mathrm{p}<0.05, * * \mathrm{p}<0.01$ and $* * * \mathrm{p}<0.001$.Viability of cells is determined by Trypan Blue. The Values are expressed as triplicates in 3 independent experiments. Error bars represent the standard error (SE) of the results. 


\section{Cytotoxicity of Pectin and MCP}

The cytotoxicity of pectin or MCP was studied on HaCaT cells using the colorimetric LDH detection test. This required first optimization of the concentration of the cells seeded, since different amounts of LDH are released by different cell types. Briefly, HaCaT cells were seeded into 96-well microtiter plates (Thermo Labsystems) at different concentrations $\left(10 \times 10^{3}, 1 \times 10^{3}\right.$, $5 \times 10^{3}$, and $2.5 \times 10^{3}$ cells.well ${ }^{-1}$ ) till an optimum density of $5 \times 10^{3}$ cells.well ${ }^{-1}$ was determined (Data not shown). This concentration was adopted for the rest of the cytotoxicity experiments.

The cells were seeded in a 96-well plate for 24 hours, after which they were treated with pectin or MCP at different concentrations $(1,10,100,300,500$, and $750 \mu \mathrm{g} / \mathrm{ml})$. MCP could not be evaluated at $750 \mu \mathrm{g} / \mathrm{ml}$. The percentage cytotoxicity of pectin on $\mathrm{HaCaT}$ cells ranged between $8.77 \%$ and $38.57 \%$ at $1 \mu \mathrm{g} / \mathrm{ml}$ and $750 \mu \mathrm{g} / \mathrm{ml}$ pectin respectively (Figure 3). The inhibitory concentration at which $50 \%$ of the cells die $\left(\mathrm{IC}_{50}\right)$ could not be determined at the pectin concentrations tested.

Cytotoxicity of MCP showed a dose-dependent effect on the cell line studied and $\mathrm{IC}_{50}$ of MCP was obtained at $500 \mu \mathrm{g} / \mathrm{ml}$ (Figure 4). Cytotoxicity of pectin and MCP was further investigated on benign (A5) and malignant (II-4) cell lines but no significant decrease in viability was detected (data not shown).

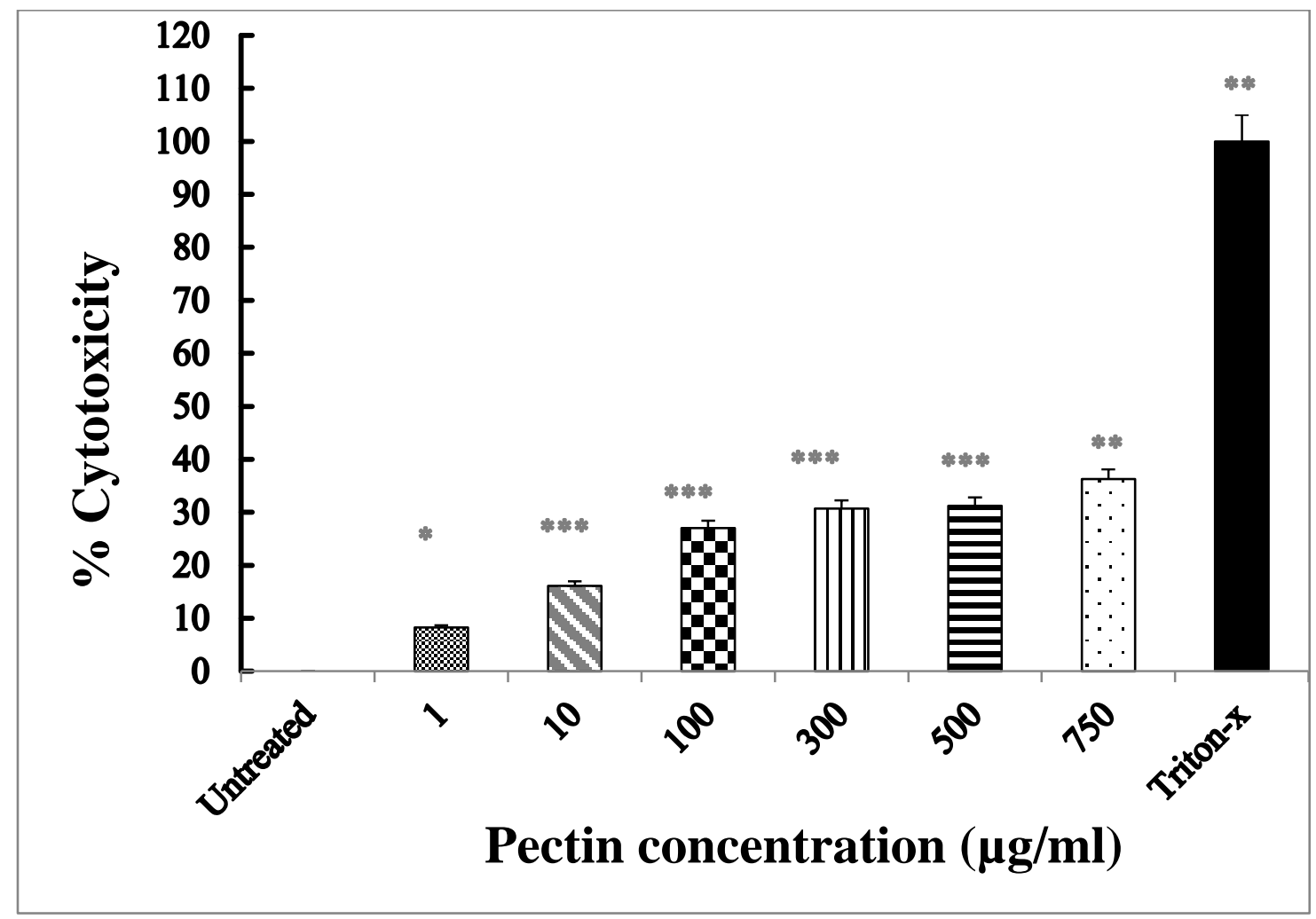

Figure 3: Cytotoxicity of Pectin on HaCaT at 24 hrs Measured by LDH Cytotoxicity Assay. Statistical significance of each group compared to the untreated control is determined as follows: $* \mathrm{p}<0.05$, $* * \mathrm{p}<0.01$ and $* * * \mathrm{p}<0.001$. The values are expressed as triplicates in 3 independent experiments. Error bars represent the standard error (SE) of the results. 


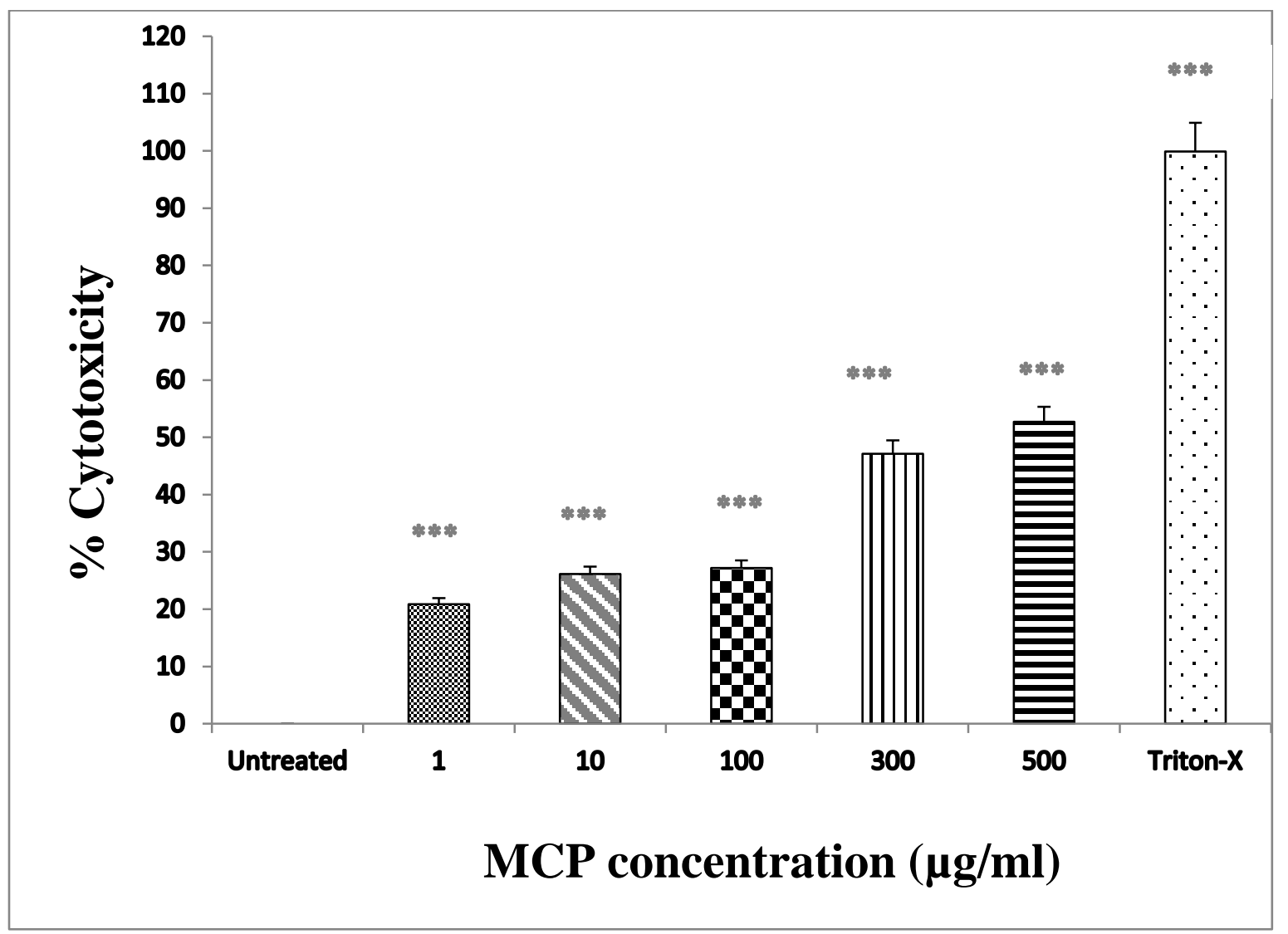

Figure 4: Cytotoxicity of MCP on HaCaT at 24 hrs Measured by LDH Cytotoxicity Assay. Statistical significance of each group compared to the control is determined as follows: $* p<0.05$, ** $p<0.01$ and $* * *$ $\mathrm{p}<0.001$. The values are expressed as triplicates in 3 independent experiments. Error bars represent the standard error (SE) of the results.

\section{Anti-proliferative Activity of Pectin on HaCaT Cells}

The anti-proliferative activity of different concentrations of pectin on the HaCaT cell line was studied using the WST1 proliferation assay at a density of $2.5 \times 10^{3}$ cells/well [21]. Incubation time for the WST-1 reagent varies between 0.5 to 4 hours according to the cell type and different concentrations of cells used (WST-1 Catalogue). The optimal incubation time according to conditions of this study was at 4 hours (Data not shown). The negative control consisted of untreated cells or cells without pectin/MCP treatment. Whereas the positive control consisted of treating cells with ethanol in order to inhibit proliferation $[17,18]$.

The anti-proliferative activity of pectin on $\mathrm{HaCaT}$ cell line was dose-dependent and ranged from $21.1 \%$ to $40.73 \%$ at concentrations $1 \mu \mathrm{g} / \mathrm{ml}$ and $750 \mu \mathrm{g} / \mathrm{ml}$ respectively (Figure 5). Higher pectin concentrations could not be tested due to solidification of the sample. MCP exhibited stronger growth inhibitory effects on the $\mathrm{HaCaT}$ cells studied. It ranged from $27.3 \%$ antiproliferative activity at $1 \mu \mathrm{g} / \mathrm{ml}$ to $72.1 \%$ at $500 \mu \mathrm{g} / \mathrm{ml} \mathrm{MCP} \mathrm{(Figure} \mathrm{6).} \mathrm{There} \mathrm{was} \mathrm{no} \mathrm{need} \mathrm{to} \mathrm{test}$ $\mathrm{MCP}$ at higher concentration since it is of interest to test anti-proliferative activity at noncytotoxic concentrations. $\mathrm{IC}_{50}$ which corresponds to concentration that causes $50 \%$ antiproliferative activity was detected at a concentration of $300 \mu \mathrm{g} / \mathrm{ml} \mathrm{MCP}$. 


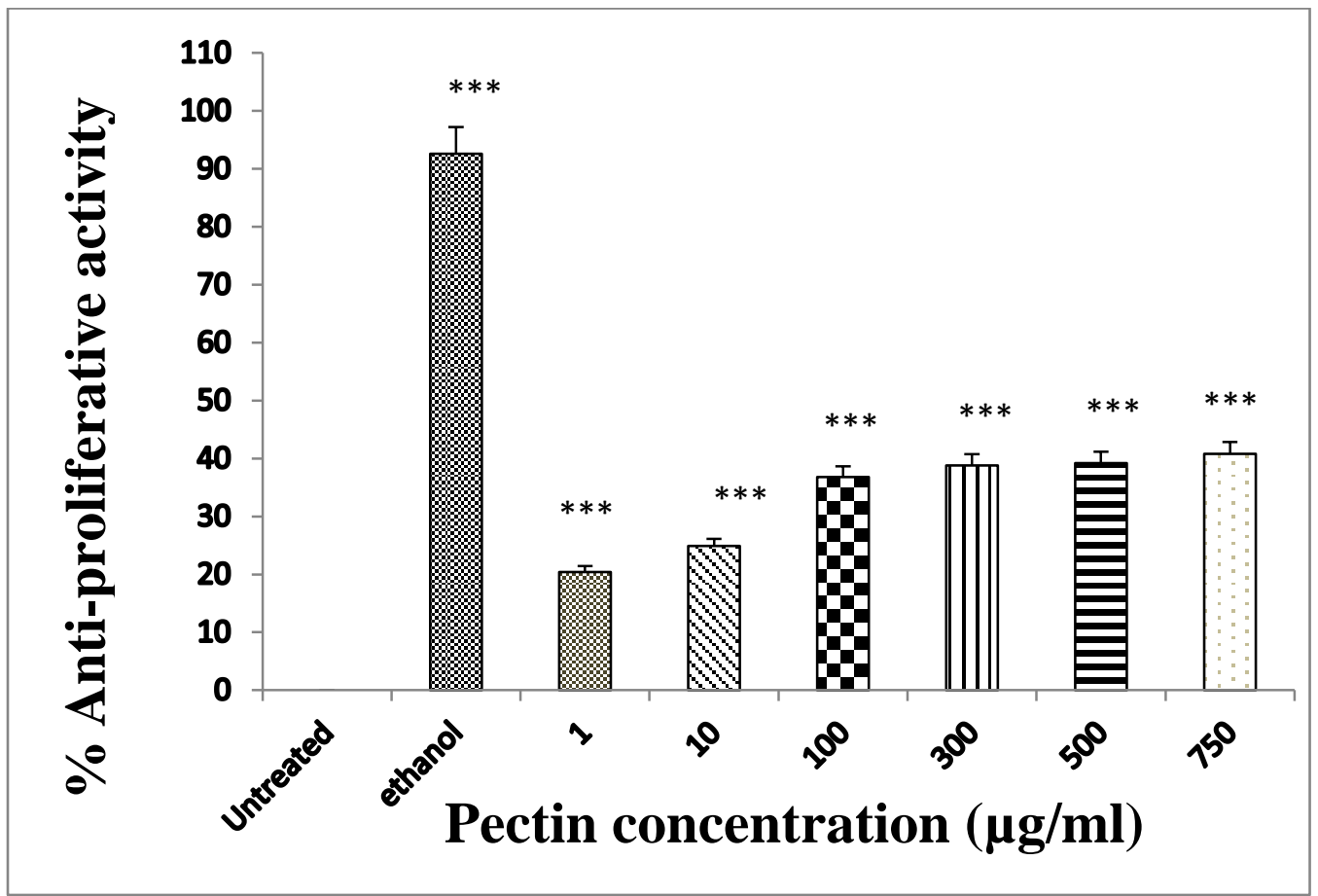

Figure 5: Effect of Pectin on HaCaT Cell Line Proliferation as Measured by WST-1 Proliferative Assay. The cells were exposed to pectin for 24 hours. The absorbance was measured at $450 \mathrm{~nm}$ and the background was subtracted. Ethanol (50\%) was used as a positive control. The values are expressed as triplicates in 3 independent experiments. Statistical significance of each group compared to the untreated control was determined by one-way ANOVA; $* \mathrm{p}<0.05, * * \mathrm{p}<0.01$ and $* * * \mathrm{p}<0.001$.

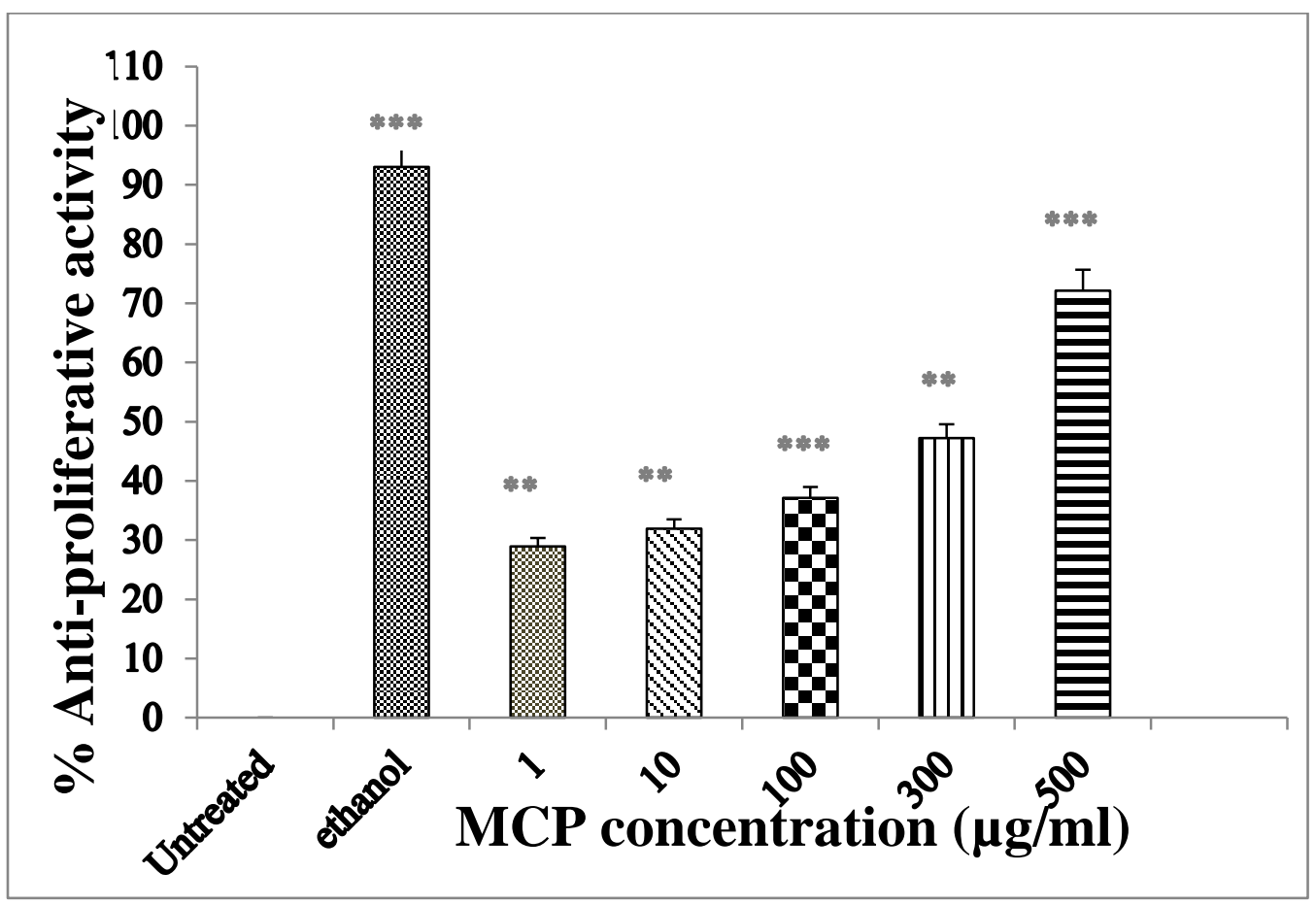

Figure 6: Effect of MCP on HaCaT Cell Line Proliferation as Measured by WST-1 Proliferative Assay. The cells were exposed to MCP for 24 hours. Ethanol was used as a positive control. The absorbance was measured at 450 $\mathrm{nm}$ and the background was subtracted. The values are expressed as triplicates of 3 independent experiments. Statistical significance was determined by One-Way ANOVA; *p $<0.05, * * \mathrm{p}<0.01$ and $* * * \mathrm{p}<0.001$. 


\section{Pectin and MCP Scavenging Activity}

Scavenging activity of Pectin and MCP against the 1,1-diphenyl-2-picrylhydrazyl (DPPH) radicals was measured at $515 \mathrm{~nm}$ using a Micro-plate Reader. A decrease in the absorbance indicates that antioxidant substances reduced the DPPH radical inducing a color change from violet to yellow. Propyl gallate was used as a standard antioxidant (Sigma-Aldrich, catalog).

Scavenging activity of pectin and MCP was dose dependent. A decrease in absorbance was obtained due to increasing concentrations $(0.125,0.25,0.5,1,2$, and $4 \mathrm{mg} / \mathrm{ml})$ of pectin or MCP. The antioxidant effect of pectin reached $16.41 \%$ at $4 \mathrm{mg} / \mathrm{ml}$. $\mathrm{SC}_{50}$ which corresponds to the intersection point between the scavenging and the antioxidant activities could not be determined for pectin due to solidification of the samples with concentrations exceeding $4 \mathrm{mg} / \mathrm{ml}$ (Figure 7).

MCP exhibited a stronger antioxidant effect. The maximum antioxidant activity (37.5\%) obtained was at $4 \mathrm{mg} / \mathrm{ml} \mathrm{MCP}$ and $\mathrm{SC}_{50}$ corresponded to a concentration range between 2 and $4 \mathrm{mg} / \mathrm{ml}$ (Figure 8 ).

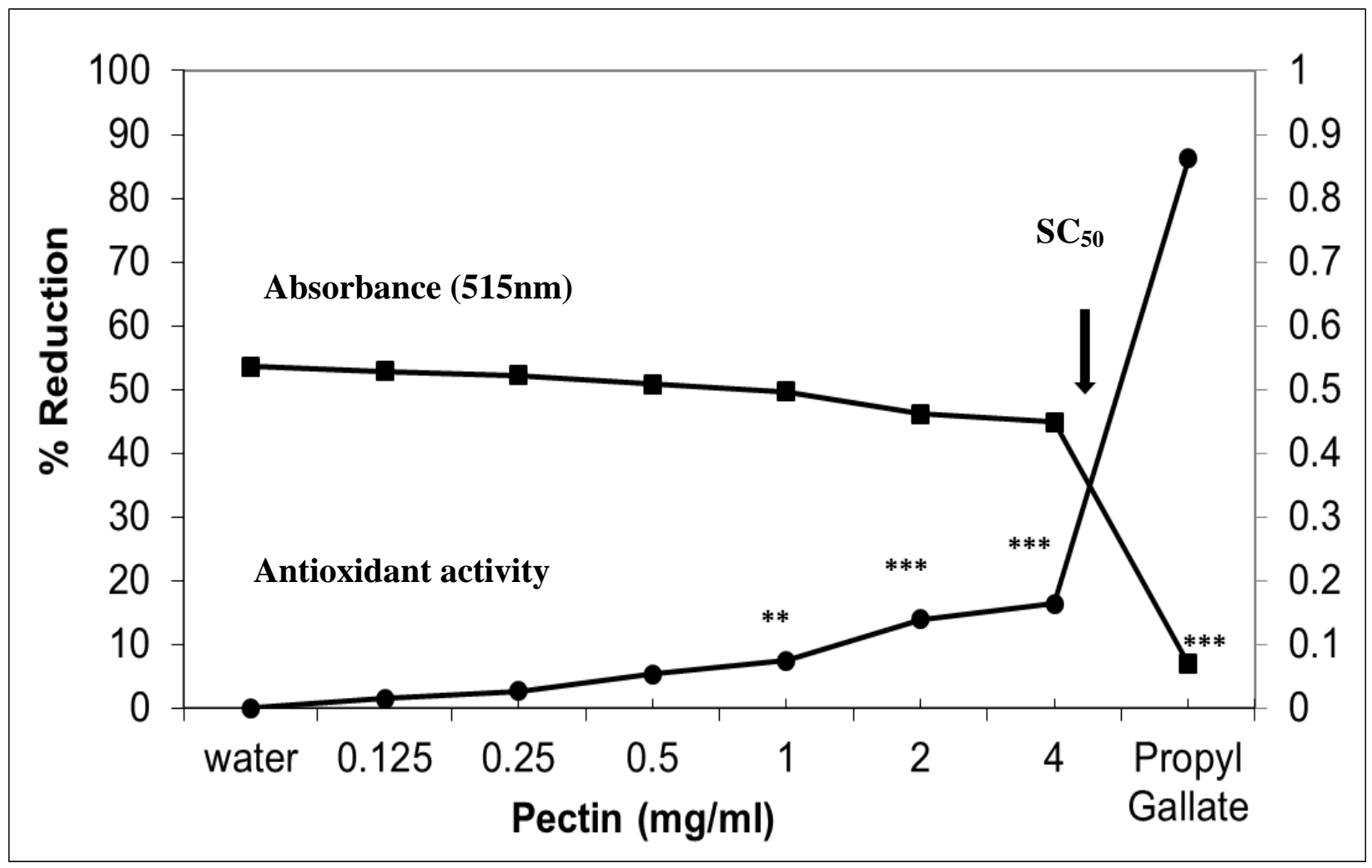

Figure 7: Combined Data for the Antioxidant and Scavenging Activities of Pectin. $\mathrm{SC}_{50}$ corresponds to the value of the intersection point of these two curves. $\mathrm{SC}_{50}$ could not be determined (at concentrations tested) due to solidification of the samples with concentrations exceeding $4 \mathrm{mg} / \mathrm{ml}$. Propyl Gallate was used as a positive control and water as a negative control. The circles represent the antioxidant activity. The squares represent the absorbance at $515 \mathrm{~nm}$. Statistical significance of each group was compared to water and determined by one-way ANOVA; ${ }^{*} \mathrm{p}<0.05, * * \mathrm{p}<0.01$ and $* * * \mathrm{p}<0.001$. 


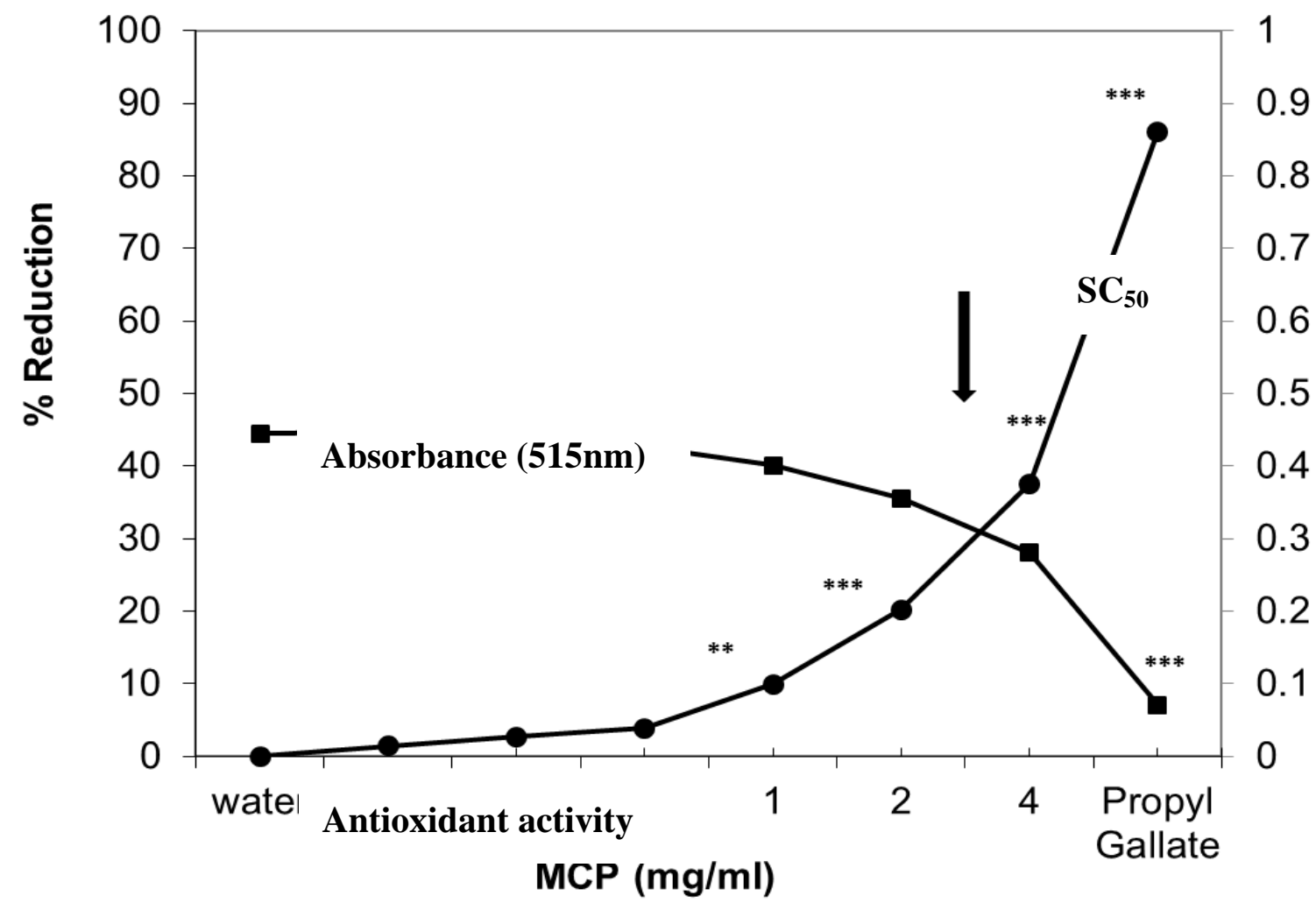

Figure 8: Combined Data for the Antioxidant and Scavenging Activities of $\mathbf{M C P}$. $\mathrm{SC}_{50}$ corresponds to the value of the intersection point of these two curves. Propyl Gallate was used as a positive control and water as a negative control. The circles represent the antioxidant activity. The squares represent the absorbance at $515 \mathrm{~nm}$. Statistical significance of each group was compared to water and determined by one-way ANOVA; *p $<0.05$, $* * \mathrm{p}<0.01$ and $* * * \mathrm{p}<0.001$.

\section{DISCUSSION}

Researchers have focused on medicinal plants as natural cures for many diseases, including cancer [22]. The present study evaluates the potential anticancer effects of different forms of pectin on $\mathrm{HaCaT}$ cell line. Pectin, a water soluble fiber present in the cell wall of plant tissues, has a very wide spectrum of biological activities including anti-inflammatory, anti-bacterial, and heart related effects [23-26]. The mechanisms of actions of both pectin and its modified forms are still not understood. The complexity of the structure, the differences in extraction methods, different sources, and different fragmentation techniques make it hard to determine the active molecule(s). Therefore, Pectin and MCP may exert different effects on different cell lines and mouse models $[27 ; 1 ; 28 ; 2 ; 5]$.

In this study, HaCaT cell line was chosen as an easy handled substituent for human keratinocytes, particularly because it has been broadly used for several studies of pharmacological and mechanistic nature [22]. The current study evaluates the cytotoxicity of both pectin and MCP on the immortalized HaCaT cell line. Both Trypan blue and LDH assays were used to assess the viability of $\mathrm{HaCaT}$ after being treated with either pectin or MCP for 24 hours. Pectin had a moderate cytotoxic activity with a maximum of $38.57 \%$ at $750 \mu \mathrm{g} / \mathrm{ml}$ (Figure 3), while MCP had an $\mathrm{IC}_{50}$ at around $500 \mu \mathrm{g} / \mathrm{ml}$ (Figure 4). Cytotoxicity was dose-dependent with 
both pectin and MCP. The cytotoxicity of MCP (Pectasol and Pectasol-C) has been demonstrated on malignant cell lines including androgen independent prostate cancer cell lines (PC3 and CASP 1.1) where Pectasol was discovered to inhibit MAP kinase activation [29; 5].

In this study, pectin had a relatively significant anti-proliferative activity with respect to the untreated control. A higher effect was obtained with MCP treatment which also caused a dosedependent reduction in the viability of the immortalized cell line. $\mathrm{IC}_{50}$ was detected at a concentration of $300 \mu \mathrm{g} / \mathrm{ml}$ (Figure 6). The anti-proliferative effect of pectins on malignant cells has been attributed to various mechanisms. A study done by Okhami et al. [30] reports that pectin plays a protective role in colon carcinogenesis by reducing the activity of bacterial betaglucoronidase, a colonic enzyme involved in the development of cancer in its initial stages [31]. Another study explains how pectin blocks the beta-catenin from increasing in murine colon cells and thereby prevents colonic cells from progressing to hyperplasia [32]. It must be noted that pectin also induces apoptosis in different malignant cell lines [31]. According to Olano-Martin et al. [33], the incubation of pectin with HT-29 cells (colon carcinoma cell lines) induced a significant increase in apoptosis. The same effect was observed on human-derived prostate cancer cells, where fractionated pectin caused a $40 \%$ increase in apoptotic-activity when compared with the untreated cells [13]. Among the galectin-3 inhibitors, many researchers focused on pectin, taking into account how it varies according to its sources and its low toxicity [12]. As a result, it has been suggested that the higher the amount of galectins expressed on the surface of malignant cells, the more anti-proliferative effect is exhibited by pectins [34].

HaCaT cells exhibit high levels of galectin-7 expression. Galectin-7 is known to be a marker of epithelial differentiation highly expressed in the stratified epithelium of different cells [35]. Studies have reported its homology to galectin-1 and galectin-3 after analyzing its 3D structure [36]. In a study done by Bergman et al. [31], citrus pectin exerted a marked antiproliferative activity on HuCC and HT-29 human derived colon carcinoma cell lines and to some extent on K562 erythroleukemia cell line. However, it showed no effect on the proliferation of Raji cells which are a prototype of Burkitt lymphoma cell line. It was observed that the inhibitory effect of pectin was only related to cells expressing galectin receptors. Raji cells lacked the ability to endogenously produce galectin and therefore were not affected when subjected to citrus pectin [31].

This study suggests a moderate cytotoxic and anti-proliferative activity of pectin compared with its degradation product. MCP is a strong galectin-3 inhibitor [12], and thereby demonstrated a higher anti-proliferative effect. The reason for this may be due to the modifications of pectin that lead to the neutral sugars cleavage that generate arabinogalactans and galactans abundantly. According to Gao et al. [12], MCP was able to inhibit galectin-3 due to the rhamnogalacturonan RG-I contained in its structure and more specifically due to galactans. Galactans obtained from RG-I in potato pectin after its enzymatic treatment [37] are capable of the selective binding to galectin-3 [38].

Several studies have suggested that antioxidant extracts from plants target one of the cancer hallmarks by scavenging excessive free radicals and inhibiting the oxidative stress effects [39]. The current study shows that both pectin and modified citrus pectin exhibit a dose-dependent antioxidant activity. MCP exhibited higher scavenging activity than pectin at the same concentration with a lower absorbance and a better antioxidant activity. 


\section{CONCLUSION}

In conclusion, pectin and its modified form seem to exert anti-tumor activity on the HaCaT cell line to different extents. This is probably due to different mechanisms of action exerted by the different active fragments depending on the chemical structure of pectin/MCP [5]. Some studies attribute the role of pectin/MCP to galactose side chains [40]. These side-chains might be masked in pectin and exposed in $\mathrm{MCP}$, thereby allowing $\mathrm{MCP}$ but not pectin to bind to their appropriate receptors on $\mathrm{HaCaT}$ cells.

We have investigated cells and conditioned media of the three human keratinocyte cell lines $\mathrm{HaCaT}$ (non-tumorigenic), A5 (benign, tumorigenic) and II-4 (malignant, tumorigenic).

Pectin and MCP had a stronger effect on cell viability on HaCaT cells but not on the tumorigenic cell lines. Further work should be performed to study the mechanism of action of pectin/MCP and to determine the active molecules that specifically interact with galectin-3. Further studies should be done in order to find out the action of pectic polysaccharides on other galectins and their effect on cancer and to identify the specific active part of pectin (galactan or other) involved in the anti-proliferative activity.

\section{Competing interests}

The authors declare that they have no competing interests.

\section{Authors' contributions}

RAM conceived the design of the work and was involved in the analysis, interpretation, manuscript preparation and manuscript reviewing. $\mathrm{VH}$ and $\mathrm{MAB}$ were involved in conducting experimental procedures, data analysis and manuscript revision. VH was involved in conducting experiments related to $\mathrm{HaCaT}$ cell-lines and in manuscript preparation. MAB was mostly involved with A5 and II4 cell lines.

\section{Acknowledgements}

We would like to thank Mr. Samer Bazzi for his help with the cell culture.

\section{REFERENCES}

1. Vincken JP, Schols HA, Oomen RJ, McCann MC, Ulvskov P, Voragen AG, Visser RG: If homogalacturonan were a side chain of rhamnogalacturonan I: implications for cell wall architecture. Plant Physiol 2003, 132(4):1781-1789.

2. Niture SK and Refai L: Plant pectin: A potential source for cancer suppression. American J Pharmacol Toxicol 2013, 8(1):9-19.

3. Voragen AG, Coenen GJ, Verhoef RP, Schols HA: Pectin, a versatile polysaccharide present in plant cell walls. Struct Chem 2009, 20(2):263-275.

4. Manderson K, Pinart M, Tuohy KM, Grace WE, Hotchkiss AT, Widmer W, Yadhav MP, Gibson GR, Rastall RA: In vitro determination of prebiotic properties of oligosaccharides derived from an orange juice manufacturing by-product stream. Appl Environ Microbiol 2005, 71(12):8383-8389.

5. Leclere L, Van Cutsem P, Michiels C: Anti-cancer activities of $\mathrm{pH}$-or heat-modified pectin. Front Pharmacol 2013, 4: Article 128 (1-8). 
6. Malhotra SL: Dietary factors in a study of cancer colon from cancer registry, with special reference to the role of saliva, milk and fermented milk products and vegetable fibre. Med Hypotheses 1977, 3(3):122-126.

7. Segal I, Hassan H, Walker ARP, Becker P, Braganza J: Fecal short chain fatty acids in South African urban Africans and whites. Dis Colon Rectum 1995, 38(7):732-734.

8. Wollowski I, Rechkemmer G, Pool-Zobel BL: Protective role of probiotics and prebiotics in colon cancer. Am J Clin Nutr 2001, 73 suppl (2):451s-455s.

9. Courts FL: Profiling of modified citrus pectin oligosaccharide transport across Caco-2 cell monolayers. PharmaNutrition 2013, 1(1), 22-31.

10. Kidd P: A new approach to metastatic cancer prevention: Modified citrus pectin (MCP), a unique pectin that blocks cell surface lectins. Altern Med Rev 1996, 1:4- 10

11. Hayashi A, Gillen AC, Lott JR: Effects of daily oral administration of quercetinchalcone and modified citrus pectin on implanted colon-25 tumor growth in Balb-c mice. Altern Med Rev 2000, 5:546-552.

12. Gao X, Zhi Y, Zhang T, Xue H, Wang X, Foday AD, Zhou Y: Analysis of the neutral polysaccharide fraction of $\mathrm{MCP}$ and its inhibitory activity on galectin-3. Glycoconj Journal 2012, 29(4):159-165.

13. Jackson CL, Dreaden TM, Theobald LK, Tran NM, Beal TL, Eid M, Gao MY, Shirley RB, Stoffel MT, Kumar V, Mohnen D: Pectin induces apoptosis in human prostate cancer cells: Correlation of apoptotic function with pectin structure. Glycobiology 2007, 17(8): 805-819.

14. D’Orazio JA, Jarrett S, Marsch A, Lagrew J, Cleary L: Melanoma-epidemiology, genetics and risk factors. In L. Davids (Ed.) 2013: Recent advances in the biology, therapy and management of Melanoma, 1-34: InTech.

15. Boukamp P, Peter W, Pascheberg U, Altmeier S, Fasching C, Stanbridge EJ, Fusenig NE: Step-wise progression in human skin carcinogenesis in vitro involves mutational inactivation of $\mathrm{p} 53$, rasH oncogene activation and additional chromosome loss. Oncogene 1995, 11(5):961-969.

16. Fusenig NE, Boukamp P: Multiple stages and genetic alterations in immortalization, malignant transformation, and tumor progression of human skin keratinocytes. Mol Carcinogen 1998, 23(3):144-158.

17. Vaughan RA, Garcia-Smith R, Bisoffi M, Trujillo KA, Conn CA: Treatment of human muscle cells with popular dietary supplements increase mitochondrial function and metabolic rate. Nutrit Metab 2012, 9:101.

18. Vandebriel RJ, Pennings JL, Baken KA, Pronk TE, Boorsma A, Gottschalk R, Van Loveren H: Keratinocyte gene expression profiles discriminate sensitizing and irritating compounds. Official Journal of the Society of Toxicol Sci 2010, 117(1):81-89.

19. Kitao S, Teramoto M, Yamaguchi T, Takamura H, Matoba T: Stabilizing effect of grape seed extract on ascorbic acid. Food Sci Technol Res 2006, 12(1):15-21.

20. Ryu, SH, Moon SY, Yang YJ, Moon SR, Hong JP, Choi J, Lee SW: Recombinant human epidermal growth factor accelerates the proliferation of irradiated human fibroblasts and keratinocytes in vitro and in vivo. J Radiat Res 2009, 50(6):545-552. 
21. Kuonen R, Weissenstein U, Urech K, Kunz M, Hostanska K, Estko M, Heusser P, Baumgartner S: Effects of lipophilic extract of Viscum album L. and oleanolic acid on migratory activity of NIH/3T3 fibroblasts and on HaCaT keratinocytes. Evid-Based Compl Alt 2013, 1-7.

22. Pastore S, Lulli D, Potapovich AI, Fidanza P, Kostyuk VA, Dellambra E, De Luca C, Maurelli R, Korkina LG: Differential modulation of stress-inflammation responses by plant polyphenols in cultured normal human keratinocytes and immortalized HaCaT cells. J Dermatol Sci 2011, 63(2):104-114.

23. Jenkins DJ, Leeds AR, Gassull MA, Cochet B, Alberti KGM: Decrease in postprandial insulin and glucose concentrations by guar and pectin. Ann Intern Med 1977, 86(1):2023.

24. Rabbani GH, Teka T, Zaman B, Majid N, Khatun M, Fuchs G J: Clinical studies in persistent diarrhea: Dietary management with green banana or pectin in Bangladeshi children. Gastroenterology 2001, 121(3):554-560.

25. Triplehorn C and Millard PS: A rice-based diet with green banana or pectin reduced diarrhea in infants better than a rice-alone diet. ACP J Club 2002;136(2):67.

26. Veldman FJ, Nair CH, Vorster HH, Vermaak WJ, Jerling JC, Oosthuizen W, Venter CS: Possible mechanisms through which dietary pectin influences fibrin network architecture in hypercholesterolaemic subjects. Thromb Res 1999, 93(6):253-264.

27. Ridley BL, O'Neill MA, Mohnen D: Pectins: Structure, biosynthesis, and oligogalacturonide-related signaling. Phytochemistry 2001, 57(6): 929-967.

28. Khotimchenko M, Shilova N, Lopatina K, Khotimchenko Y, Zueva E: Modified pectin compounds exert different effects on Ehrlich Ascites tumor cells and Lewis Lung carcinoma and on efficiency of cyclophosphamide in mice. J Med Sci 2007, 7(3):383389.

29. Yan J and Katz A: PectaSol-C modified citrus pectin induces apoptosis and inhibition of proliferation in human and mouse androgen-dependent and-independent prostate cancer cells. Integr Cancer Ther 2010, 9(2):197-203.

30. Ohkami H, Tazawa K, Yamashita I, Shimizu T, Murai K, Kobashi K, Fujimaki M: Effects of apple pectin on fecal bacterial enzymes in azoxymethane-induced rat colon carcinogenesis. Jpn J Cancer Science 1995, 86(6):523-529.

31. Bergman M, Djaldetti M, Salman H, Bessler H: Effect of citrus pectin on malignant cell proliferation. Biomed Pharmacother 2010, 64(1):44-47.

32. Umar S, Morris AP, Kourouma F, Sellin JH: Dietary pectin and calcium inhibit colonic proliferation in vivo by differing mechanisms. Cell Proliferat 2004, 36(6):361-375.

33. Olano-Martin E, Gibson GR, Rastall RA: Comparison of the in vitro bifidogenic properties of pectins and pectic-oligosaccharides. J of Appl Microbiol 2002, 93(3):505511.

34. Satelli A, Rao PS, Gupta PK, Lockman PR, Srivenugopal KS, Rao US: Varied expression and localization of multiple galectins in different cancer cell lines. Oncol Rep 2008, 19(3):587-594.

35. Campion CG, Labrie M, Lavoie G, St-Pierre Y: Expression of galectin-7 is induced in breast cancer cells by mutant p53. PLoS One 2013, 8(8):e72468. 
36. St-Pierre Y, Campion CG, Grosset AA: A distinctive role for galectin-7 in cancer? Front BioSci 2012, 17:438-450.

37. Gunning AP, Bongaerts RJ, Morris VJ: Recognition of galactan components of pectin by galectin-3. FASEBJ 2009, 23(2):415-424.

38. Gunning AP, Pin C, Morris VJ: Galectin 3-beta-galactobiose interactions. Carbohydr Polym 2013, 92:529-533.

39. Thatte U, Bagadey S, Dahanukar S: Modulation of programmed cell death by medicinal plants. Cell Mol Biol (Noisy-le-grand) 2000, 46(1):199-214.

40. Yu CY, Wang YM, Li NM, Liu GS, Yang S, Tang GT, He DX, Tan XW, Wei H: In vitro and in vivo evaluation of pectin-based nanoparticles for hepatocellular carcinoma drug chemotherapy. Mol Pharmaceut 2014, 11(2):638-644. 